DEVELOPMENT OF MANAGEMENT

AND ENTREPRENEURSHIP METHODS

ON TRANSPORT, № 4 (77), 2021
РОЗВИТОК МЕТОДІВ

УПРАВЛІННЯ ТА ГОСПОДАРЮВАННЯ

НА ТРАНСПОРТІ, № 4 (77), 2021
УДК 338.48

JEL Z32

DOI 10.31375/2226-1915-2021-4-141-157

\section{ОСОБЛИВОСТІ УПРАВЛІННЯ} СФЕРОЮ ТУРИЗМУ В УКРАЇНІ

В УМОВАХ АДМІНІСТРАТИВНОТЕРИТОРІАЛЬНОЇ РЕФОРМИ

\author{
А.М. Іванов \\ к.е.н., доцент \\ кафедри «Підприємництво та туризм» \\ Одеський начіональний морський університет, \\ м. Одеса, Украӥна
}

Анотація. У статті досліджено особливості управління сферою туризму Украӥни в історичному періоді з часів ї̈ незалежності до сьогоднішнього дня.

На основі загальноприйнятих світових моделей управління сферою туризму та найбільш характерних для иих моделей країн виявлено модель, яка найбільш характерна та ефективна для Украӥни на сучасному етапі.

В умовах адміністративно-територіальної реформи, яка має місие в Украӥні, виявлені позитивні та негативні складові ї̈ впливу на розвиток сфери туризму на рівні об'єднаних територіальних громад.

Надані рекомендації щодо підвищення ефективності управління туризмом як сферою господарського комплексу України з урахуванням існуючої адміністративно-територіальної реформи, яка може кардинально вплинути на розвиток туризму та спровокувати надзвичайно високі ризики.

Запропоновані шляхи ефективного уnравління туризмом на рівні об'єднаних територіальних громад.

Розроблена модель управління сферою туризму. Модель розділена на державні органи прямого $і$ непрямого впливу, а також недержавні органи впливу та включає новий для України орган місцевого управління об'єднані територіальні громади, контрагентів та постачальників. Модель охоплює державні та місиеві органи влади, туристичні підприємства та громадські організачії усіх форм власності прямого та непрямого впливу, поєднуючи усі складові в єдине иіле.

Ключові слова: туризм, управління туризмом, модель управління, адміністративнотериторіальна реформа, ОТГ, туристичний магніт.

(C) Іванов A.M., 2021
УДК 338.48

JEL Z32

DOI 10.31375/2226-1915-2021-4-141-157

\section{ОСОБЕННОСТИ УПРАВЛЕНИЯ \\ СФЕРОЙ ТУРИЗМА В УКРАИНЕ \\ В УСЛОВИЯХ АДМИНИСТАТИВНО- ТЕРРИТОРИАЛЬНОЙ РЕФОРМЫ}

\author{
А.Н. Иванов \\ к.э.Н., доцент \\ кафедры «Предпринимательство и туризм» \\ Одесский национальный морской университет \\ 2. Одесса, Украина
}

Аннотация. В статье исследованы особенности управления сферой туризма Украины в историческом периоде со времен ее независимости до сегодняшнего дня.

На основе общепринятых мировых моделей управления сферой туризма и наиболее характерных для этих моделей стран выявлена модель, которая наиболее характерна и эффективна для Украины на современном этапе.

В условиях административно-территориальной реформы, которая имеет место в Украине, выявлены положительные и отрицательные составляющие ее влияния на развитие сферы туризма на уровне объединенных территориальных общин.

Даны рекомендации по повышению эффективности управления туризмом как сферой хозяйственного комплекса Украины с учетом существующей административно-территориальной реформы, которая может кардинально повлиять на развитие туризма и спровочировать очень высокие риски.

Предложень пути эффективного управления туризмом на уровне объединенных территориальных обшин.

Разработана модель управления сферой туризма. Модель разделена на государственные органы прямого и непрямого влияния, а также негосударственные органы влияния и включает в себя новый для Украины орган местного управления - объединенные территориальные обичины, контрагентов и поставщиков. Модель включает государственные и местные органы власти, туристические предприятия и общественные организации всех форм собственности прямого и непрямого влияния, объединяя все составляюшие в единое иелое.

Ключевые слова: туризм, управление туризмом, модель управления, административно-территориальная реформа, ОТО, туристический магнит. 
UDC 338.48

JEL Z32

DOI 10.31375/2226-1915-2021-4-141-157

\title{
FEATURES OF TOURISM MANAGEMENT IN UKRAINE IN THE CONDITIONS OF ADMINISTRATIVE-TERRITORIAL REFORM
}

\author{
Andrii Ivanov \\ $\mathrm{PhD}$ in Economic, Associate Professor \\ of the Department of Entrepreneurship and Tourism \\ andriy5555@i.ua \\ Odessa National Maritime University, Odessa, Ukraine
}

\begin{abstract}
The article examines the features of the management of the tourism sector in Ukraine in the historical period from the time of its independence to the present day. Tourism as a sphere of the economic complex of Ukraine began to develop only in 1991. Until 1991, tourism was not included in either the production or non-production sphere of activity, but was defined as a type of activity that provides the consumer with intangible benefits. Since 1991, the role and place of tourism in the structure of the economic complex has changed more than once.

On the basis of the generally accepted world models of tourism management and the countries most characteristic of these models, it was revealed that the most characteristic and effective model for Ukraine at the present stage is a model similar to the French, when a profile ministry is involved in state regulation, which includes a profile Agency, and management at the regional level is included in the competence of tourism departments established by local authorities and tourism departments at the OTG level.

Most tourism and hospitality associations and agencies are ineffective and should be reformed to improve the effectiveness of managerial influence.

In the context of the administrative-territorial reform that is taking place in Ukraine, the positive and negative components of its influence on the development of the tourism sector at the level of the united territorial communities have been identified. Most of the OTGs do not understand their role and the possibility of effectively influencing tourism management, thereby preventing the development of either individual tourist sites or the sphere in general. Recommendations are given to improve the efficiency of tourism management as a sphere of the economic complex of Ukraine, taking into account the existing administrative-territorial reform, which can radically affect the development of tourism and provoke very high risks.

The ways of effective tourism management at the level of united territorial communities are proposed.

A model for managing the tourism sector has been developed, which includes state bodies of direct and indirect influence, as well as non-state bodies of influence, as well as a new non-existing structural management unit, united territorial communities. The model includes state and local authorities, tourism enterprises and public organizations of all forms of ownership of direct and indirect influence, uniting all components into a single whole.
\end{abstract}

Keywords: tourism, tourism management, management model, administrativeterritorial reform, UTG, tourist magnet. 
Постановка проблеми. Затяжна соціально-економічна та політична кризи призвели до суттєвого зменшення обсягів діяльності та значної втрати туристичного потенціалу України. На розвиток туризму також вплинуло реформування органів місцевого самоврядування, завдяки якому суттєво зменшено кількість районів та укрупнено територіальні громади. Поява об'єднаних територіальних громад (далі - ОТГ) по-різному вплинула на сучасний та подальший стан розвитку туристичної сфери України.

Однак реформа місцевого самоврядування, переслідуючи головну мету у наданні більших повноважень органам місцевого самоврядування та збільшення доходів на рівні ОТГ, має по-новому вплинути на умови та структуру управління розвитком туризму на усіх рівнях - від громад до міністерств. Саме тому наукове обгрунтування моделі управління сферою туризму в Україна на сучасному етапі $є$ важливим та актуальним.

Огляд останніх досліджень та літератури. Дослідженням проблем управління сферою туризму в Україні присвячені наукові праці відомих вітчизняних учених: М. Біржакова, М. Босовської, Д. Вєдєніна, В. Герасименка, В. Данильчука, В. Кифяка, О. Любіцевої, А. Мазаракі, М. Мальської, А. Охріменко, Т. Ткаченко, В. Семенова, В. Цибуха, В. Федорченка та інших.

В іноземній і вітчизняній літературі проблеми управління туризмом на рівні держави розглядалися в працях Є. Богданова, Д. Боуена, Р. Браймера, С. Ванхілла, Д. Гілберта, Л. Гринів, М. Долішнього,
О. Дуровича, I. Зоріна, М. Кабушкіна, О. Кузьміна, К. Купера, Ю. Масюк, Н. Раскіна, Д. Флетчера та ін.

Питанням регіонального управління сферою туризму присвячені праці Н. Гончарук [1], Н. Гостєвої [2], Т. Шелеметьєвої [3] та інших.

Однак час йде і разом з ним переосмислюються у науковому та практичному сенсі бачення сучасного та стратегічного управління туризмом. Думки вчених та практиків туристичного бізнесу з цього приводу суттєво різняться, не маючи єдиного підходу до створення ефективної моделі, завдяки якій туризм став провідною галуззю господарського комплексу України [4-9].

Отже, проведений нами аналіз наукових праць українських та зарубіжних учених довів, що мало дослідженими залишаються проблеми управління розвитком туризму в контексті реформування адміністративно-територіальної реформи в Україні, яка впроваджується сьогодні в державі.

Постановка задачі. Головною задачею статті $\epsilon$ виявлення позитивних та негативних складових, які впливають та можуть здійснити вплив на управління та розвиток туризму в умовах функціонування об'єднаних територіальних громад як складової адміністративно-територіального поділу України, а також запропонувати шляхи підвищення ефективності діяльності ОТГ на шляху розвитку регіонального туризму, створити сучасну модель управління сферою туризму тощо. 
DEVELOPMENT OF MANAGEMENT

AND ENTREPRENEURSHIP METHODS ON TRANSPORT, № 4 (77), 2021
РОЗВИТОК МЕТОДІВ

УПРАВЛІННЯ ТА ГОСПОДАРЮВАННЯ

НА ТРАНСПОРТІ, № 4 (77), 2021
Основний матеріал дослідження. Туризм як сфера господарського комплексу України почала розвиватися лише 3 початку незалежності держави. В часи СРСР туризм не був включений ні до виробничої, ні до невиробничої сфери діяльності, що було вкрай неефективним, оскільки туризм поряд із торгівлею, харчуванням та зв'язком вважався тим напрямком діяльності, що знаходиться на межі виробничої та невиробничої сфери, забезпечуючи споживача нематеріальними благами [4; 5]. Починаючи з 1991 року зі зміною моделі господарського комплексу в Україні, роль та місце туризму змінювалися не один раз.

Сьогодні на думку багатьох учених у світі існує три моделі управління сферою туризму:

1) перша модель: управління на принципах відсутності єдиного державного органу управління;

2) друга модель - централізоване державне управління із наданням повноважень щодо управління єдиному державному органу влади (міністерству, відомству);

3) третя модель: державне управління із наданням повноважень управління різним державним органам влади, кожне з яких відповідає за вузький специфічний лише для нього вид діяльності [10].

При обранні відповідної моделі управління туристичні ринки країн можуть бути емісійними та рецептивними.

Для 3'ясування існуючої моделі управління туризмом в Україні у 2021 році розглянемо особливості управління туризмом у 6-ти державах світу як найбільш характерних представників цих моделей.

Німеччина. Функції державного регулювання у сфері туризму $\mathrm{Hi}$ меччини виконує Федеральне міністерство економіки та енергетики, в рамках якого діє Німецький центр туризму (Deutsche Zentrale für Tourismus, скорочено DZT). Головний офіс розташований у м. Франкфурт-наМайні. DZT має 30 представництв за кордоном, у тому числі 11 власних філій та 19 офісів, що діють під егідою партнерських організацій. Просування Німеччини як туристичного напряму поділено на шість основних географічних областей. У Німеччині мають місце спеціальні туристичні центри Tourist Information.

Великобританія. Центральним органом державного регулювання у сфері туризму $є$ Міністерство культури, засобів масової інформації та спорту, у рамках якого функціонує національне агентство з туризму «VisitBritain» (HTA Великобританіï). «VisitBritain» має змішане фінансування: близько 2/3 їі бюджету становлять фінанси, які надходять від держави, 1/3 - від комерційної діяльності. «VisitBritain», яка $\epsilon$ державно-приватною структурою, вибудовує довгострокове стратегічне партнерство 3 британським туристичним бізнесом, найбільші представники якого входять до Ради директорів «Visit-Britain».

Найбільш впливовою недержавною туристичною організацією $є$ «Travel Association», яка налічує понад 5000 турагентств та близько 900 туроператорів (на добровільній основі) та лобіює їхні інтереси у Парламенті. Більшість туристичних компаній-членів «Travel Association» 
DEVELOPMENT OF MANAGEMENT

AND ENTREPRENEURSHIP METHODS ON TRANSPORT, № 4 (77), 2021
РОЗВИТОК МЕТОДІВ

УПРАВЛІННЯ ТА ГОСПОДАРЮВАННЯ

НА ТРАНСПОРТІ, № 4 (77), 2021 мають ліцензію ATOL, яка є фінансовою схемою захисту туристів, у тому числі й від банкрутства турфірми.

Японія. Державне регулювання сфери туризму в Японії покладено на Міністерство землі, інфраструктури, транспорту та туризму, у рамках якого діє Японське агентство туризму (JTA) та виконує функції НТА з 2008 року по сьогоднішній час. Також функціонує некомерційна Японська національна туристична організація (JNTO). Організацією туризму в Японії займаються спеціалізовані туристичні фірми (туроператори та турагенти). Відповідно до законів всі вони зобов'язані мати ліцензію на заняття туристичної діяльністю. В Японії існує чотири види туристичних фірм, які мають задовольняти певні умови.

США. Розвитком туризму в США займається Національний Офіс індустрії туризму та подорожей (The Office of Travel and Tourism Industry, скор. ОТТI), що діє у складі Міністерства торгівлі США та належить до Відділу виробництва та сервісу при Адміністрації міжнародної торгівлі. Крім ОТТІ існує Консультативна рада 3 подорожей та туризму (Travel \& Tourism Advisory Board, скор. ТТАВ), яка створена у 2003 році. Вона $є$ органом, що допомагає Міністру торгівлі США вирішувати питання, пов'язані з розвитком індустpiï туризму та подорожей. У турбізнесі США діє недержавна організація «Американське товариство туристичних агентств» (American Society of Travel Agents, ASTA), членами якої $\epsilon$ представники туристичних фірм, постачальників окремих видів туристич- них послуг, розташованих у 140 країнах світу.

Франція. Державним регулюванням туристичної діяльності у Франції займається Міністерство ремесел, торгівлі та туризму, в рамках якого діє Агентство 3 туристичного розвитку Франції Atout France (Переваги Франціiі), яке є об'єднанням на економічній основі понад 1300 партнерів-професіоналів у сфері туризму, включаючи місцеві туристичні адміністрації, турфірми, засоби розміщення, підприємства харчування, транспортні організації, окремі туристичні об'єкти та ін. Державним фінансуванням забезпечується близько $50 \%$ усіх витрат «Atout France», а решта коштів залучається з боку приватних компаній, зацікавлених у розвитку туристичного бізнесу.

Регіональний рівень управління туристичною сферою Франції представлений комітетами 3 туризму, створеними місцевими урядами, фінансування яких відбувається від регіональних рад.

Туреччина. Державне регулювання туристичної галузі здійснює Міністерство культури i туризму та має представництва майже в 30 країнах світу, у тому числі і в Україні. Діяльність туристичних підприємств підлягає державному ліцензуванню, яка видається Міністерством культури та туризму Туреччини після обов'язкової реєстрації підприємства в Асоціації турецьких туристичних фірм TÜRSAB. У Туреччині існують три види ліцензій залежно від послуг, які надають туристичні підприємства.

Як бачимо, оптимальної загальноприйнятої моделі не існує, оскільки у кожної країни мають місце спе- 
цифічні передумови, властиві лише ій, від яких залежить управління сферою туризму на державному рівні: історичні, політичні, демографічні, економічні, соціальні і ін.

Якщо враховувати наведені вище особливості загальноприйнятих моделей управління туристичною сферою, слід зробити наступні висновки з інтерпретацією для України:

1) управління сферою туризму в Україні ніколи не було близьким до першої моделі;

2) у певний історичний період було схожим із другою моделлю, коли туризм функціонував у складі Міністерства економічного розвитку та торгівлі, а пізніше - до Міністерства молоді та спорту;

3) сьогодні, як і в попередній час, для управління туризмом на дер- жавному рівні характерна близькість та схожість із третьою світовою моделлю, коли управлінням займаються різні міністерства - Міністерство економічного розвитку та торгівлі, Міністерство молоді і спорту, Міністерство цифрової трансформації, Miністерство розвитку громад та територій України, Міністерство фінансів України, Міністерство культури та інформаційної політики та інші.

Станом на 2021 рік управління туризмом в Україні належить до сфери діяльності Міністерства культури та інформаційної політики, у складі якого функціонує центральний орган державної виконавчої влади у сфері туризму - Державне агентство розвитку туризму України (рис. 1).

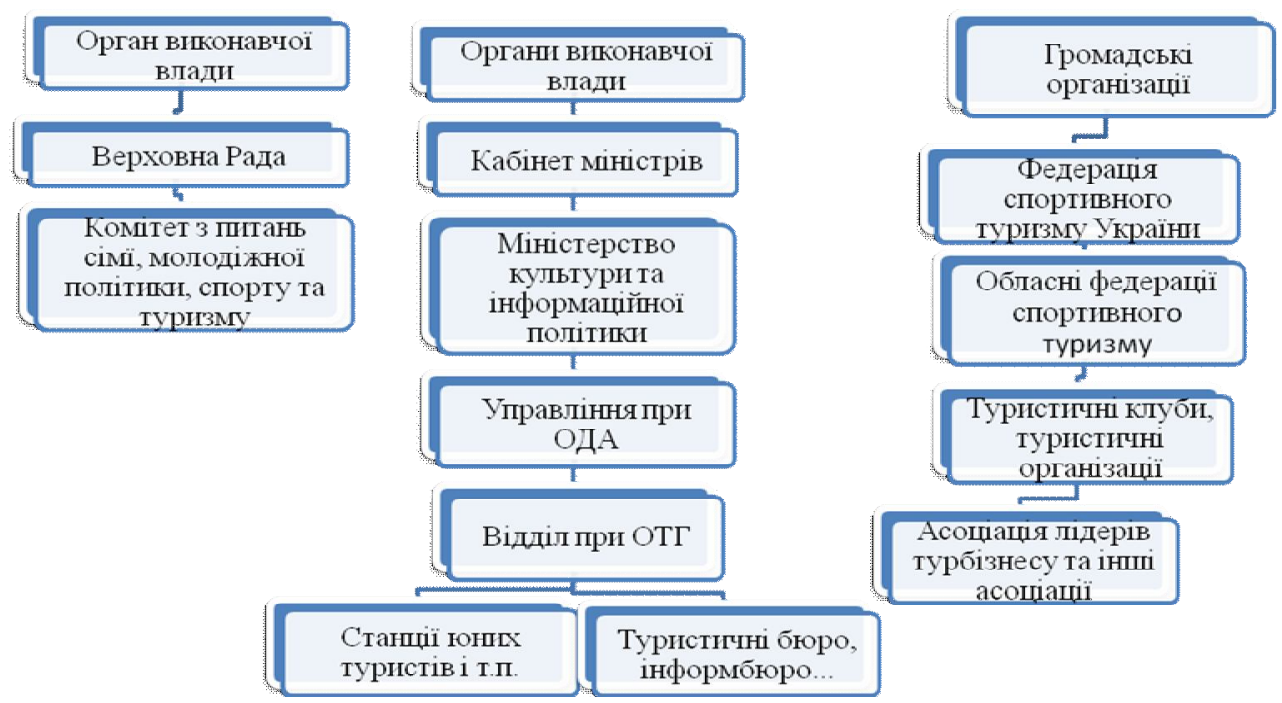

Рис. 1. Місие туризму у структурі державного управління Украйни (в обласних иентрах України управління мають різні назви, поєднуючись з різними видами діяльності)

Джерело: складено автором (за власним баченням) 
На сьогоднішній день думки науковців 3 приводу ефективності управління туристичною сферою в Україні різняться. Але більшість учених впевнені у недосконалості обраної в Україні моделі. Як приклад - Франція від туризму отримує доходів до бюджету країни в десятки разів більше, ніж Україна, в якій схожа модель управління із французькою.

Так, Ю.О. Масюк та інші вважають, що підпорядкування туризму будь-якому міністерству (включаючи Мінекономрозвитку) без створеної та функціонуючої профільної громадської організації та Національного туристичного агентства, не принесе користі [11]. Але створення та функціонування в Україні сьогодні НТОУ та Державного агентства розвитку туризму України на наш погляд також не призвели до розвитку туризму у порівнянні 3 тими періодами, коли їх не існувало, оскільки бюрократія підпорядкування, пандемія Covid-19 та інші об'єктивні та суб'єктивні фактори гальмують розвиток туризму як на місцевому, так i на загально-державному рівнях.

Ще меншу ефективність в управлінні сферою туризму на загально-державному рівні виконують такі громадські організації як Асоціація лідерів туристичного бізнесу, Асоціація туроператорів та турагентів України, Асоціація дитячого та молодіжного туризму та інші, які мають негнучку, бюрократичну інституціональну організаційну структуру, величезну кількість неефективних учасників і як результат - низький вплив на розвиток туризму.

Неоднозначно також на розвиток туризму вплинула адміністративно-територіальна реформа, яка реалізується в Україні з 2015 року по сьогоднішній час, переслідуючи головну мету у наданні більших повноважень органам місцевого самоврядування і зміні адміністративно-територіального поділу задля більших доходів на місцевому рівні. Планується замість понад 11000 місцевих рад сформувати 1469 спроможних територіальних громад, а замість 490 районів створити 136 нових районів із передачею основних повноважень рад районів на нижчий (ради громад) i вищий (ради областей) рівні [12-14].

Так, станом на кінець 2021 року в межах 3-х південних областей України сформовано 16 районів та 192 ОТГ (таблиця).

Табличя

Зміни адміністративно-територіального поділу південних областей України

\begin{tabular}{|l|c|c|c|c|}
\hline $\begin{array}{c}\text { Назва } \\
\text { області }\end{array}$ & $\begin{array}{c}\text { Кількість ОТГ } \\
\text { станом } \\
\text { на 2021 рік }\end{array}$ & $\begin{array}{c}\text { Кількість } \\
\text { районів станом } \\
\text { на 2021 рік }\end{array}$ & $\begin{array}{c}\text { Кількість } \\
\text { районів станом } \\
\text { на 2015 рік }\end{array}$ & $\begin{array}{c}\text { Різниця } \\
\text { кількості районів 2020 } \\
\text { до 2015 рр. (+,-) }\end{array}$ \\
\hline Одеська & 91 & 7 & 26 & -19 \\
\hline Миколаївська & 52 & 4 & 19 & -15 \\
\hline Херсонська & 49 & 5 & 18 & -13 \\
\hline
\end{tabular}

Джерело: складено автором на основі [12-14] 
DEVELOPMENT OF MANAGEMENT

AND ENTREPRENEURSHIP METHODS ON TRANSPORT, № 4 (77), 2021
Укрупнення районів та створення нових ОТГ має по-іншому формувати туристичну політику держави, даючи поштовх для інвестицій, зайнятості трудових ресурсів, збільшення потоку туристів і як результат - доходів на різних рівнях. Але на сьогоднішній день розвиток туризму в умовах функціонування ОТГ в Україні має як переваги, так і недоліки. нести:

До сильних сторін слід від-

1. Створення сприятливих соціально-економічних умов для розвитку туризму у складі ОТГ.

2. Розвиток кадрового потенціалу громади.

3.Підвищення туристичної привабливості та створення сучасного позитивного туристичного іміджу громади.

4. Створення умов для роботи іноземних та вітчизняних туристичних операторів та груп.

5. Сприяння розвитку окремих туристичних об'єктів (магнітів).

6. Можливість концентрації фінансів, отриманих завдяки туризму саме на розвиток цієї галузі в ОТГ.

7. Можливість в межах ОТГ раціонального перерозподілу фінансів між громадами на розвиток туризму та окремих об'єктів (магнітів).

8. Можливість підтримки соціальних програм в межах ОТГ.

9. Можливість розвивати інші галузі (кластерна модель).

10. Спрощення документообігу для малого та середнього бізнесу.

До слабких сторін слід віднести:

1. Незадовільний рівень роботи 3 координації туризму в ОТГ.

2. Низький рівень якості послуг.
3. Відсутність більшості державних стандартів та норм для функціонування закладів індустрії туризму.

4. Недостатній рівень реклами та застосування PR-технологій для просування туризму в ОТГ.

5. Низький рівень конкурентності послуг індустрії туризму в межах ОТГ.

6. Незадовільний рівень інфраструктури.

7. Непривабливий зовнішній вигляд об'єктів в історичній частині населених пунктів та на основних маршрутах.

8. Низький рівень прибутковості підприємств індустрії туризму.

9. Високий рівень плинності кадрів в індустрії туризму.

10. Недостатній рівень матеріально-технічної бази підприємств сфери туризму.

11. Недостатній рівень співпраці між населенними пунтами ОТГ.

12. Низький рівень обсягів продажів місцевих турпродуктів.

13. Недосконалий рівень роботи комунальних служб.

14. Низький рівень співпраці в секторі туризму та між секторами.

15. Недостатній рівень розвитку спеціалізованих видів туризму, які б могли стати ключовими у рамках ОТГ.

16. Відсутня інвентаризація турресурсів та турпродуктів.

17. Недостатній рівень інформації про місто та околиці на мовах туристів.

18. Короткий термін перебування туриста на території громад ОТГ. 
DEVELOPMENT OF MANAGEMENT

AND ENTREPRENEURSHIP METHODS
РОЗВИТОК МЕТОДІВ

УПРАВЛІННЯ ТА ГОСПОДАРЮВАННЯ

НА ТРАНСПОРТІ, № 4 (77), 2021
19. Відсутність бачення перспектив та напрямків розвитку туризму ОТГ.

20. Відсутні нові турмаршрути та турпродукти громад ОТГ.

21. Не завжди високий рівень патріотизму місцевих жителів громад ОТГ.

22. Недостатній рівень співпраці закладів освіти 3 питань розвитку внутрішнього туризму громад OTГ

23. Відсутність системи підготовки та перепідготовки кадрів на рівні ОТГ.

24. Переважна більшість найбільш привабливих об'єктів на території ОТГ не належать їй, а управляється державою на самих високих рівнях (музеї, фортеці, охоронні територіï).

Як бачимо, на сьогоднішній день недоліків набагато більше, ніж переваг. Звичайно, кожен недолік $\epsilon$ сенс перетворити у позитивне русло. Тому вважаємо для ефективного функціонування туризму у складі ОТГ реалізацію наступних заходів:

1. Забезпечення діяльності Регіональних туристичних організацій громад ОТГ 3 метою підвищення якості послуг, просування.

2. Співпраця 3 туристичними підприємствами громад ОТГ, партнерство.

3. Сприяння підвищенню якості туристичних послуг громад ОТГ.

4. Регулярні засідання Координаційної Ради з питань туризму ОТГ.

5. Організація професійних презентаційних, освітніх заходів до Всесвітнього дня туризму, ініціювання та проведення тематичних форумів для секторів туризму.
6. Заходи для підвищення туристичного потоку в громаду в період сезону та міжсезоння.

7. Розробка та запровадження системи громадського контролю якості послуг, що надаються об’єктами туристичної інфраструктури.

8. Моніторинг потреб, оцінка логістики, розробка та запровадження системи супроводу туристів у громадах ОТГ.

1. Розробка та просування системи «Онлайн гід», переклад на іноземні мови.

2. Розробка системи та проведення моніторингу діяльності об'єктів туристичної інфраструктури та суб'єктів підприємницької діяльності у сфері надання послуг, пов'язаних 3 організацією відпочинку та подорожей громадян.

3. Аудит, оцінка та затвердження вимог до екскурсійних програм по території громад ОТГ.

4. Створення та затвердження положення про правила здійснення екскурсійної діяльності в громаді.

5. Співпраця із закладами сфери туризму громад щодо підвищення якості послуг сфери обслуговування.

6. Створення реєстру та постійне оновлення електронної бази даних підприсмств туристично-рекреаційного комплексу громад ОТГ.

7. Проведення інвентаризації та паспортизації об'єктів культурної спадщини згідно з Державними стандартами.

8. Моніторинг потреб суб'єктів індустрії туризму, розробка плану дій, щодо їх задоволення та покращення. 
DEVELOPMENT OF MANAGEMENT

AND ENTREPRENEURSHIP METHODS ON TRANSPORT, № 4 (77), 2021
9. Створення реєстру та постійне оновлення електронної бази даних об'єктів туристичної інфраструктури громади ОТГ.

10. Проведення заходів із пропаганди серед жителів міста (цільових груп: освіта, підприємства, службовці) перспектив розвитку туристичної галузі шляхом організації круглих столів, екскурсій, навчань, конкурсів.

11. Створення програми фінансування ініціатив діяльності громадських організацій, що сприяють розвитку туризму в громадах ОТГ.

12. Розробка та видання інформаційних матеріалів з метою популяризації різних видів туризму.

13. Сприяння розширенню мережі та різноманітності гуртків та заходів для популяризації пізнавального, культурного та активного туризму серед дітей та молоді громад ОТГ.

14. Сприяння запровадженню сучасних інтерактивних Інтернет-сервісів для підвищення якості інфраструктури та надання послуг туристам та мешканцям громад 3 можливістю громадянам висловлювати власну думку з приводу якості послуг iз використанням Інтернет-ресурсів

15. Вивчення перспектив та створення туристичного кластеру.

16. Сприяння промоції транспортної інфраструктури громади (зупинка автобусів, авто, залізничний вокзал, автостанція, річковий (морський) вокзал).

17. Представлення туристичного потенціалу громад на туристичних виставках.

18. Забезпечення поширення на міжнародному та всеукраїнському рівні інформації про заходи в сфері туризму в рамках Дня громади.

19. Посилення співпраці з населеними пунктами-побратимами.

20. Створення туристичної $\mathrm{IH}-$ тернет-сторінки туристичної тематики та забезпечення іiі системного оновлення та розміщення промоційних матеріалів про туристичний потенціал громад ОТГ.

21. Сприяння співпраці туристичних підприємств 3 навчальними закладами, які готують спеціалістів для туристичної сфери.

22. Пропагування в засобах масової інформації переваг внутрішнього туризму громад ОТГ.

23. Проведення семінарів-навчань, тренінгів для представників туристичних підприємств, громадських організацій щодо організації в 'їзного туризму громад ОТГ.

24. Забезпечення проведення туристичних екскурсійних програм для школярів початкової та середньої школи, місцевих жителів тощо.

25. Створення реєстру та затвердження списку головних подій громади (фестивалі, ярмарки, форуми), та винесення його на вищий рівень (село-громада-район-областьрегіон).

26. Організація різноманітних конкурсів та програм для створення позитивного туристичного іміджу громад ОТГ.

27. Створення інформаційних друкованих та електронних матеріалів для представлення туристичного потенціалу громад ОТГ.

28. Підтримка нових культурних ініціатив 3 метою підвищення туристичної привабливості громад ОТГ. 
29. Проведення інвентаризації та створення реєстру культурних пам'яток за історико-культурними періодами громад ОТГ.

30. Оцінка та аналіз, розробка пропозицій, створення системи туристичної навігації у громаді, у т.ч. організація виготовлення та встановлення туристичних вказівників (туристичних стовпів-покажчиків, покажчиків різних напрямків, туристичних карт-схем, стендів туристичної інформації, інформаційних білбордів та сітілайтів, туристичних стендів тощо).

31. Сприяння популяризації сучасних форматів проведення акцій 3 популяризації екскурсійного туризму в громаді - квестів, флеш-мобів, вуличних перформенсів тощо по усім районам громади.

32. Сприяння створенню та популяризації сучасних інтерактивних засобів поширення інформації із застосуванням QR-кодів на основних об'єктах туристичної інфраструктури.

33. Сприяння запровадженню громадських ініціатив щодо поширення в мережі Інтернет інформації про громаду та туристичні об'єкти: гасло, логотип та ін.

34. Співпраця 3 іноземними громадськими організаціями, ЗВО України, товариствами, закордонними діаспорами, налагодження обміну групами та проведення спільних культурних акцій для створення позитивного туристичного іміджу громад ОТГ.

35. Розширення співпраці 3 містами/громадами побратимами щодо реалізації культурних акцій, спрямованих на розвиток спільних соціо- культурних ініціатив та розвиток туристичних обмінів.

36. Сприяння розвитку спеціалізованих видів туризму - розробка карт-схем, дороговказів (популярними іноземними мовами), облаштування місць стоянки транспортних засобів, кемпінгів, місць зупинок в громадах ОТГ.

37. Розроблення проєктів та сприяння їх втіленню щодо привабливого зовнішнього вигляду фасадів будівель, автомобільних в'їздів до громад, у т.ч. дизайну вітальних написів, благоустрою території, картсхем та дизайну оригінального освітлення.

38. Розробка системи заходів щодо супроводу іноземних туристів.

39. Забезпечення наявності електронних матеріалів та розміщення ïx $\mathrm{y}$ мережі Інтернет на іноземних мовах.

40. Забезпечення підтримки установам громад під час проведення міжнародних конференцій (роздаткові матеріали, сувеніри).

41. Ефективний вибір туристичних магнітів, які б у подальшому могли бути центрами туристичної привабливості та отримували найбільше фінансування.

42. Створення списку магнітів вторинного списку, які б могли стати послідовниками основних.

43. Впроваджувати соціальні програми для різних верств населення громади, тим самим рекламуючи об'єкти туризму та сферу туризму в цілому.

44. Намагатися за рахунок розвитку туризму створити кластерну модель, яка б дозволила за рахунок розвитку туризму «потягнути» за 
DEVELOPMENT OF MANAGEMENT

AND ENTREPRENEURSHIP METHODS ON TRANSPORT, № 4 (77), 2021
РОЗВИТОК МЕТОДІВ

УПРАВЛІННЯ ТА ГОСПОДАРЮВАННЯ

НА ТРАНСПОРТІ, № 4 (77), 2021 собою розвиток інших сфер діяльності - транспортних мереж, АПК тощо.

Що стосується основного нововведення у змінах функціонування туризму в умовах ОТГ - це створення так названих «туристичних магнітів», яке запропоновано для впровадження 32021 року Державним агентством розвитку туризму України та підтримано Президентом України. Так, станом на кінець 2021 року з південних областей України лише Миколаївська ОДА узаконила після громадського обговорення головні «туристичні магніти», які внесені до Стратегії розвитку Миколаївської області, а на рівні Одеської та Херсонської ОДА обговорення продовжуються.

Так, на Миколаївщині розпочалося фінансування таких «туристичних магнітів»: Міжнародний фестиваль «Performance Jazz»; Міжнародний фестиваль «Ultra Fest Трихати», Міжнародний фестиваль «Mykolaiv Fest», Фестиваль «Івана Купала» на території Галицинівської ОТГ, Всеукраїнський фестиваль «Extreme Fest» біля Південноукраїнська, Всеукраїнський фестиваль національних культур «Дружба». Не дивлячись на це, Миколаївська ОДА не надала пріоритетів розвитку щодо тих фестів, заходів та територій, які десятками років до цього створювали туристичне «обличчя» області, наприклад, маршрути від ТФ «Хан-Тенгрі», фестиваль авторської пісні «Ольвія», фестиваль повітряних куль, розвиток курортів «Коблево», «Очаків» та ін. У Одеській та Херсонській областях взагалі не поспішають визначати пріоритетні «туристичні магніти», підтверд- женням чого є прийняті обласні Програми розвитку туризму та курортів.

Аналізуючи проблеми та перспективи розвитку туризму в умовах формування та функціонування ОТГ, пропонуємо таку модель управління сферою туризму, де державним органом прямого впливу нарешті стане Міністерство туризму та курортів (жодне інше міністерство, у якому чітко не буде визначено туризм як головну сферу діяльності, не може бути ефективним) (рис. 2).

У вертикальному підпорядкуванні управління Міністерству має підпорядковуватися управління туризму та курортів ОДА, а йому - відділи туризму та курортів новостворених ОТГ. Який комітет буде розглядати діяльність сфери туризму на рівні Верховної Ради України не має значення. Головне - щоб був результат. Звичайно, непрямий вплив мають здійснювати різні Міністерства Мінекономрозвитку, Міністерство АПК, Міністерство освіти і науки, Міністерство економічного розвитку, Miністерство екології та інші, але їх вплив має бути у межах компетентності. Непрямий вплив також мають здійснювати державні органи влади такі, як, наприклад, Державна прикордонна служба, Держкомзем, Національна поліція і т.д. Ефективність управління сферою туризму також залежить від діяльності таких державних структур як Федерація спортивного туризму України, туристичні клуби, екскурсійні бюро та інші. 


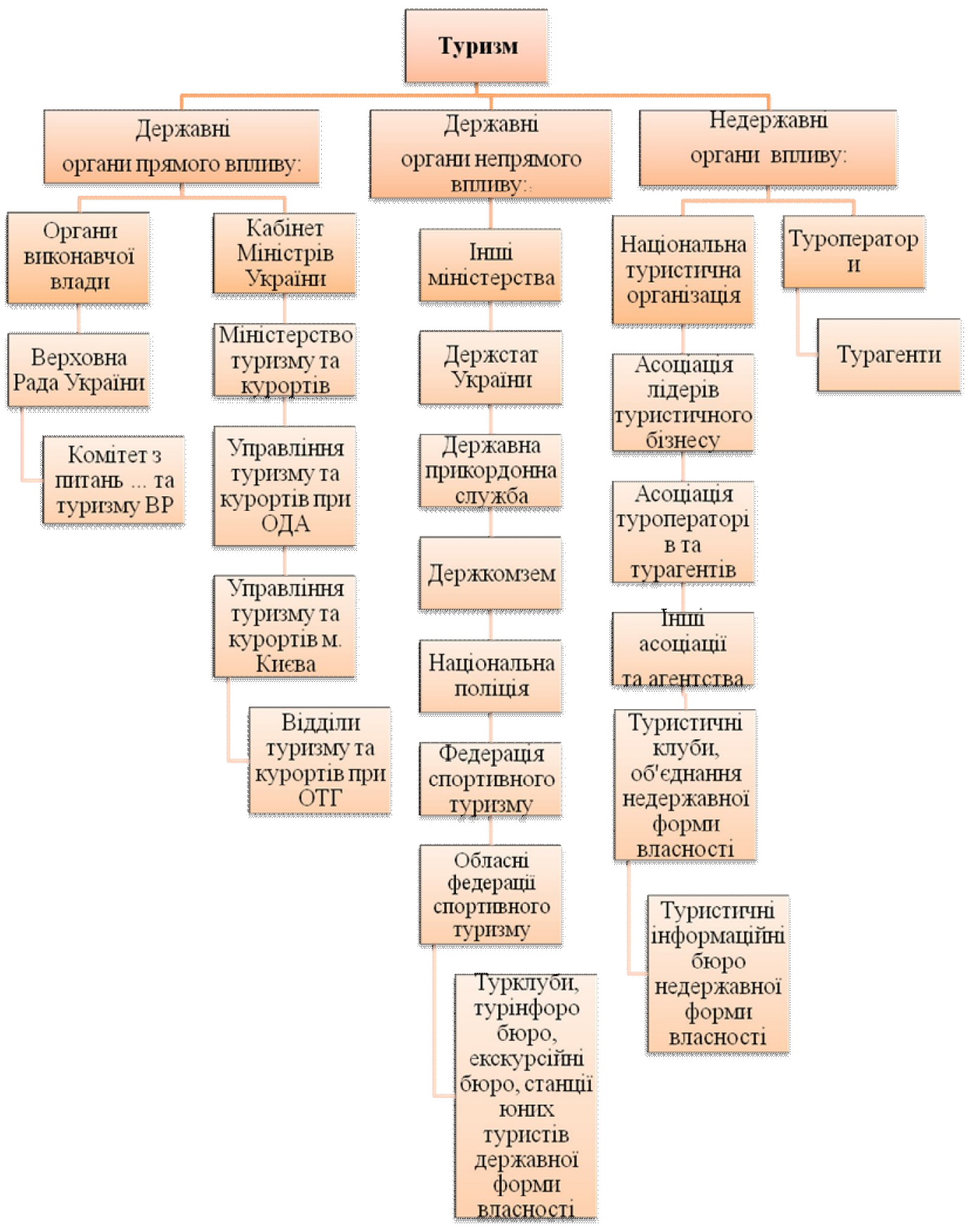

Рис. 2. Модель управління сферою туризму в Украйні

Джерело: власна розробка автора 
Головним недержавним органом управління сферою туризму в Україні має стати громадська організація НТОУ, до сфери діяльності якої мала б входити розробка та впровадження держстандартів, просування України на міжнародному ринку, об'єднання зусиль підприємств різних форм власності для узгодження пропозицій та подання їх на розгляд Міністерства туризму та курортів. Недержавні об'єднання у вигляді Асоціацій, слід створювати 3 гнучкою організаційною структурою, ефективними учасниками, на засадах державно-приватного партнерства шляхом співпраці держави, бізнесу i споживчого сектору та виконувала роль біржі праці в туризмі, а існуючі переформовувати.

Звичайно на ринку туристичної діяльності мають залишитися основні гравці ринку - туроператори, турагенти та турист як головний споживач турпослуг та турпродукту. Саме вони мають в ринковій економіці стати головним важелем, який впливає на управління сферою туризму на різних рівнях його функціонування.

Без впливу контрагентів та постачальників турпослуг ринок туризму існувати не зможе. Тому слід враховувати i цей складовий елемент структури управління.
Отже, сучасні вітчизняні реалії доводять, що сфера туризму в Україні хоч і позиціонується на рівні держави як пріоритетна галузь розвитку національної економіки, але у дійсності функціонує неефективно. Особливою проблемою стало впровадження у життя адміністративно-територіальної реформи, завдяки якій з'явилася нова структурна одиниця управління - ОТГ.

Саме відсутність належних теоретичних і методичних підходів до управління сферою туризму від ОТГ до Верховної Ради України обумовлюють необхідність формування концепції стратегічного управління цією перспективною галуззю економіки.

Висновки. Таким чином, для України доцільно реалізовувати «комбіновану» модель управління туристичною галуззю, яка передбачає створення інтегрального міністерства, яке, крім туризму, має формувати суміжні та взаємодоповнюючі напрями соціально-економічної політики, визнаючи туризм пріоритетним напрямом розвитку економіки, ефективне функціонування усіх державних та недержавних органів прямого та непрямого впливу.

\section{СПИСОК ЛІТЕРАТУРИ}

1. Гончарук Н. Система управління сферою туризму в умовах децентралізачіï влади в Україні. 2018. URL: http://www.dridu.dp.ua/vidavnictvo/ 2018/2018_04(39)/16.pdf

2. Гостєва Н.П. Адміністративний механізм державного регулювання туристичної галузі України. 2012. URL: http://www.dy.nayka.com.ua/?op= $1 \& z=513$ 
3. Шелементьєва Т.В. Управління розвитком туризму в Україні в умовах трансформації національної економіки: автореферат дис. ... д-ра екон. наук: 08.00.03. Запоріжжя, 2019. 43 с.

4. Іванов А.М. Економічні аспекти інституціонального забезпечення державної політики Украӥни в сфері туризму // Вісник Одеського національного університету. Економіка. 2018. T.23. Вип. 1 (66). C. 77-81.

5. Іванов А.М. Теоретичні основи державної політики розвитку туризму на основі маркетингового підходу в управлінні // Економіка харчової промисловості. 2016. № 1. T. 8. С. 33-39.

6. Державне регулювання сфери туризму Украӥни в контексті прочесів євроінтеграчї: монографія / За ред. В.Г. Герасименко, О.Л. Михайлюк. К.: ФОП Гулясва В.М., 2019. 332 с.

7. Іванов А.М. Шляхи удосконалення інституціонального механізму рекреаційно-туристичної політики України // Бізнес-навігатор. 2018. № 1(44). C. 72-76.

8. Іванов А.М. Інформачійне забезпечення державної політики розвитку туризму України // Вісник соціально-економічних досліджень. 2014. № 3 (25). C. 145-150.

9. Іванов А.М. Управління конкурентоспроможністю рекреаційно-оздоровчого землекористування: монографія. Миколаїв: В-во «Дизайн та Поліграфія», 2012. 248 с.

10. Леоненко Н.А. Дослідження моделей державного регулювання у сфері туризму. 2019. URL: http://www.pag-journal.iei.od.ua/archives/2019/112019/16.pdf

11. Масюк Ю.О. Стратегічне управління розвитокм туризму в Украӥні: автореферат дис. ... канд. екон. наук: 08.00.03. Львів, 2019. 25 с.

12. Децентралізація. Одеська область. URL: https://decentralization.gov.ua/ areas/0482/rayons

13. Децентралізація. Миколаӥвська область. URL: https://decentralization. gov. ua/ areas/0512/rayons

14. Децентралізація. Херсонська область. URL: https://decentralization.gov. ua/areas/0552/rayons

15. Digital technology in the management of quality service in tourism business Nezdoyminov, S., Bedradina, G., Ivanov, A. International Journal of Engineering and Advanced Technology. 2019. 9(1). P. 1865-1869.

\section{REFERENSES}

1. Goncharuk, N. (2018). Sistema upravlinnya sferoyu turizmu v umovakh detsentralizatsii vladi $v$ Ukraïni [Tourism management system in the conditions of decentralization of power in Ukraine]. Retrived from http:// www.dridu.dp.ua/vidavnictvo/2018/2018_04(39)/16.pdf [in Ukrainian]. 
2. Gostyeva, N.P. (2012). Administrativniy mekhanizm derzhavnogo regulyuvannya turistichnoï galuzi Ukraïni [Administrative mechanism of state regulation of the tourism industry of Ukraine]. Retrived from http://www.dy. nayka.com.ua/?op=1\&z=513 [in Ukrainian].

3. Shelementyeva, T.V. (2019). Upravlinnya rozvitkom turizmu v Ukrä̈ni v umovakh transformatsiï natsionalnoï ekonomiki [Management of tourism development in Ukraine in the conditions of transformation of the national economy]. Avtoreferat dis. ... d-ra ekon. nauk: 08.00.03. Zaporizhzhya, 43. [in Ukrainian].

4. Ivanov, A.M. (2018). Yekonomichni aspekti institutsionalnogo zabezpechennya derzhavnoï politiki Ukraïni $v$ sferi turizmu [Economic aspects of institutional support of the state policy of Ukraine in the field of tourism] // Visnik Odeskogo natsionalnogo universitetu. Yekonomika. T.23. Vipusk 1 (66). 77-81. [in Ukrainian].

5. Ivanov, A.M. (2016). Teoretichni osnovi derzhavnoï politiki rozvitku turizmu na osnovi marketingovogo pidkhodu v upravlinni [Theoretical bases of the state policy of development of tourism on the basis of the marketing approach in management]. Yekonomika kharchovoï promislovosti. № 1. T. 8. 33-39. [in Ukrainian].

6. Gerasimenko, V. G. \& Mikhaylyuk, O. L. (2019). Derzhavne regulyuvannya sferi turizmu Ukraïni $v$ konteksti protsesiv evrointegratsiï: monografiya [State regulation of tourism in Ukraine in the context of European integration processes]. K.: FOP Gulyaєva V.M. 332. [in Ukrainian].

7. Ivanov, A.M. (2018). Shlyakhi udoskonalennya institutsionalnogo mekhanizmu rekreatsiyno-turistichnoï politiki Ukraïni [Ways to improve the institutional mechanism of recreational and tourist policy of Ukraine]. Biznes-navigator. № 1(44). 72-76. [in Ukrainian].

8. Ivanov, A.M. (2014). Informatsiyne zabezpechennya derzhavnoï politiki rozvitku turizmu Ukraïni [Information support of the state policy of tourism development of Ukraine]. Visnik sotsialno-ekonomichnikh doslidzhen Bulletin of socio-economic research. № 3 (25). 145-150. [in Ukrainian].

9. Ivanov, A.M. (2012). Upravlinnya konkurentospromozhnistyu rekreatsiynoozdorovchogo zemlekoristuvannya: monografiya [Management of competitiveness of recreational and health land use]. Mikolaïv: V-vo "Dizayn ta Poligra-fiya», 248 [in Ukrainian].

10. Leonenko, N.A. (2019). Doslidzhennya modeley derzhavnogo regulyuvannya $u$ sferi turizmu [Research of models of state regulation in the field of tourism]. Retrived from http://www.pag-journal.iei.od.ua/archives/2019/112019/16.pdf [in Ukrainian].

11. Masyuk, Yu.O. (2019). Strategichne upravlinnya rozvitokm turizmu v Ukrä̈ni [Strategic management of tourism development in Ukraine]. Avtoreferat dis. ... kand. ekon. nauk: 08.00.03. Lviv, 2019. 25. [in Ukrainian]. 
12. Detsentralizatsiya. Odeska oblast [Decentralization. Odessa region]. Retrived from https://decentralization.gov.ua/areas/0482/rayons [in Ukrainian].

13. Detsentralizatsiya. Mikolaïvska oblast. [Decentralization. Mykolaiv region]. Retrived from https://decentralization.gov.ua/areas/0512/rayons [in Ukrainian].

14. Detsentralizatsiya. Khersonska oblast. [Decentralization. Kherson region]. Retrived from https://decentralization.gov.ua/areas/0552/rayons

15. Nezdoyminov, S., Bedradina, G. \& Ivanov, A. (2019). Tsifrovi tekhnologï v upravlinni yakisnim obslugovuvannyam u turistichnomu biznesi [Digital technology in the management of quality service in tourism business]. International Journal of Engineering and Advanced Technology. 9(1). 1865-1869.

Стаття надійшла до редакиії 12.11.2021

Посилання на статтю: Іванов А.М. Особливості управління сферою туризму в Україні в умовах адміністративно-територіальної реформи // Розвиток методів управління та господарювання на транспорті: Зб. наук. праць, 2021. № 4 (77). С. 141-157. DOI 10.31375/2226-1915-2021-4-141-157.

Article received 12.11.2021

Reference a JournalArtic: Ivanov, Andrii (2021). Features of tourism management in Ukraine in the conditions of administrative-territorial reform. Differentiation of directions for optimizing the black sea transport potential // Development of management and entrepreneurship methods on transport. 4 (77), 141-157. DOI 10.31375/2226-1915-2021-4-141-157. 